\title{
INFLUENCES OF PERSONALITY ON STUDENTS' SPEAKING PERFORMANCE
}

\author{
Truong Thi Phuong* \\ Department of Foreign Language Education, VNU University of Languages and International Studies \\ Pham Van Dong, Cau Giay, Hanoi, Vietnam \\ Received 8 February 2020 \\ Revised 18 May 2020; Accepted 18 January 2021
}

\begin{abstract}
The great demand for pair work and group work in speaking lessons at University of Languages and International Studies, Vietnam National University, Hanoi (ULIS, VNU) and the weaknesses of first-year students in those activities have been a source of inspiration to this research paper. The research paper focuses on both influences of personality on students' performance and possible recommendations to overcome the problems. To achieve these purposes, 52 first-year students and 2 experienced speaking teachers at Division 1, Faculty of English Language Teacher Education, ULIS, VNU have taken part in the data collection process including questionnaires, interviews and classroom observations. Afterwards, the data analysis detected that unstable-extroverted was the common trend of students' personality. Besides, some positive and negative influences of personality types on students' performance in pair work and group work speaking activities were found out. Based on those influences, recommendations of dividing groups and pairs as well as dividing roles and tasks for students in pair work and group work were raised to reduce the negative effects and increase positive ones.
\end{abstract}

Key words: speaking, personality, speaking activities

\section{Introduction}

English language learning and teaching has been considered an important subject in the Vietnam education system. According to the statistics by Vietnam Ministry of Education and Training (as cited in Chu, 2003), in 2003, English was taught in $98.5 \%$ of Vietnamese secondary schools. Recognizing this importance, schools and teachers are trying to improve their teaching methods. In the past, grammar and rules were the most vital element and grammar-translation was the most popular teaching method. In contrast, communication has been put into great consideration in modern society; therefore, Communicative Language Teaching (CLT) focusing on four skills: listening, speaking, reading and writing has been the main teaching approach in most schools and institutions (Chu, 2003). In this context, University of Languages and International Studies - Vietnam National University, Hanoi (ULIS, VNU) has applied CLT into teaching English and certainly four skills are carefully taught. Moreover, for some

\footnotetext{
* Tel.: 0973625003

Email: truongthiphuong.hulis@gmail.com
}

students, speaking skill is not only important but also difficult. In fact, many students cannot communicate in English although they have learnt English for seven years at high school. Therefore, speaking learning should be focused more.

In the speaking learning process, various factors can affect the effectiveness of students' learning. First, there are some objective factors such as social context, regional tradition and customs. Besides, some subjective factors include students' psychological and physical features, interests, purposes of learning and especially their own personalities. Several studies have been conducted on the relationship between personalities and the second language learning such as The Role of Personality in Second Language Acquisition (Yan, 2006) and Personality Preferences and Foreign Language Learning (Raymond, 1998). Some influences of personalities on foreign language learning process have been found out in those studies; however, not many researchers concentrate on the influences of personalities on learning speaking skill.

For those reasons, the researcher decided to conduct a study on the topic "Influences of personality on students' speaking performance" for the purpose of examining the 
influences of personalities on students' performance in speaking activities. After exploring the influences including both positive and negative ones, the study also aims at discovering several possible ways to enhance the positive effects to help students have a better result in learning. In fact, speaking skill includes both monologue and dialogue, and this study only focused on dialogue. To be specific, the study concentrated on speaking activities in which the students have to work with others.

\section{Literature review}

\section{Nature of speaking}

In 1987, Bygates (1987, as cited in Chu, 2003 , p. 5) raised a definition of speaking which is a popular form of expression using "the colloquial register". He also emphasized that "speaking is transient and improvised and can therefore be viewed as facile, superficial or glib".

From another viewpoint, Rivers (1968, cited in Tran, 1999, p. 7) considered speaking as "the selection of the message to be sent and the encoding of the message for transmission (that is, the intensive and encoding behavior of the speaker)". Different from Bygates (1987), Rivers (1968) believed that speaking is not a superficial activity but an intensive behavior.

Byrne (1976, cited in Bui, 1999, p. 8) gave another definition of speaking which is "a twoway process between the speaker(s) and the listener(s) involving the productive skills of speaking and the receptive skills of understanding". This definition focused on interactive characteristics of speaking. In his opinion, both speaker and listener had function in this process: the speaker had to encode the target message to convey it in a suitable way and the listener had to decode it.

Among these three definitions, the last one of Byrne (1976, cited in Bui, 1999, p. 8) was the most complete because it not only mentioned the speaker but also the listener. As we know, speaking is not an activity of the speaker but is an interaction between the speaker and the listener.

\section{Factors affecting speaking performance}

According to Nguyen and Tran (2015), there were four factors that affected students' speaking performance. They were performance condition, listening ability, feedback and affective factors.

\section{Performance condition}

Students perform their speaking task under certain conditions. Nguyen and Tran (2015) thought that these conditions could affect the students' performance a lot. Those conditions consist of time pressure, planning, the standard of the performance and the amount of support.

\section{Listening ability}

Speaking ability can be developed only when listening ability is improved (Doff, 1998, as cited in Nguyen \& Tran, 2015). To have a successful conversation, students must understand what is said. In a conversation, one person is not only the speaker but also the listener. Therefore, he/she cannot respond if he/she doesn't understand what is being said (Nguyen \& Tran, 2015).

\section{Feedback during speaking activities}

According to Harmer (1991), all students expect their teachers' feedback, but how the teacher gives feedback affects their speaking a lot. If the students are always stopped for mistakes, they will feel demotivating and afraid to speak in front of their friends. Harmer also suggested teacher should give feedback to their students positively and with encouragement.

\section{Affective factors}

The learners' affective side is one of the most influential factors on their speaking success or failure (Krashen, 1982, as cited in Nguyen \& Tran, 2015). Krashen stated that a number of studies confirmed the relationship between affective variables and speaking learning success.

Focusing on the connection between affective factors and speaking performance, Minghe and Juan (2013) mentioned four main factors including Motivation and Attitude, Selfesteem and Anxiety, Cross-cultural Awareness and especially Personality. In their opinion, personality is an important factor and closely relates to the students' oral performance. Specifically, they thought that students with 
different personality traits choose different speaking learning strategies. There are two obvious groups of personality traits which are extroverted and introverted. Generally, extroverted students seem to be more active in English oral performance than introverted ones. Some students have troubles in English oral performance because of their personality. However, a few teachers fail to pay proper attention to those kinds of students or just complain about their poor performance. In some cases, teachers may neglect these introverted students, which makes them feel lonely and leads to negative effects on their speaking learning.

Minghe and Juan (2013) also thought that English teacher should be aware of their students' personality types and the affective factors of personality types. Teachers should consider both extroverts and introverts when designing activities for their students. Finally, introverted students should be encouraged to take part in the activities.

To sum up, some studies show that there are some factors affecting students' speaking performance. Affective factors in general or personality in particular are important and have strong influences on the students' English oral performance.

\section{Types of personality}

According to Jung (1921), there are two basic "general attitude types": Introverted and Extroverted which "distinguished by the direction of general interest or libido movement..... differentiated by their particular attitude to the object".

Specifically, extroverted attitude "maintains a positive relation to the object" and an extravert's attitude is continually orientated by and related to the object (Jung, 1921). In contrast, the introvert's attitude to the object "is an abstracting one" and an introverted person "is always facing the problem of how libido can be withdrawn from the object". Thus, the main difference between these two kinds of attitudes is that the former is more objective when the latter is more subjective in the relation to the object.

\section{Table 1}

Extroverted and Introverted (Jung, 1921)

\begin{tabular}{ll}
\multicolumn{1}{c}{ Extroverted } & \multicolumn{1}{c}{ Introverted } \\
\hline $\begin{array}{l}\text { psychological energy is directed out of the person to } \\
\text { the world outside them } \\
\text { objective - outward }\end{array}$ & $\begin{array}{l}\text { the person's psychological energy is internally } \\
\text { directed } \\
\text { subjective - inward } \\
\text { such an extent does he affirm its importance that his }\end{array}$ \\
$\begin{array}{ll}\text { ".... attitude to the object is an abstracting one.... he } \\
\text { subjective attitude is continually being orientated } \\
\text { by, and related to the object...." (Jung, 1921) }\end{array}$ & withdrawn from the object...." (Jung, 1921) \\
\hline $\begin{array}{ll}\text { Apart from the two attitudes of extraversion } \\
\text { and introversion, Jung also developed a } \\
\text { framework of "four functional types" from } \\
\text { which the "most differentiated function plays }\end{array}$ & $\begin{array}{l}\text { or orientation to life" (Jung, 1921). It can be } \\
\text { referred that among four functional types, there } \\
\text { is one type that is dominant and able to lead to a } \\
\text { person's changes. }\end{array}$
\end{tabular}
the principal role in an individual's adaptation

Table 2

Jung's Four Functional Types - Definitions

\begin{tabular}{|c|c|c|c|}
\hline Thinking & what something is & $\begin{array}{l}\text { meaning and } \\
\text { understanding }\end{array}$ & $\begin{array}{l}\text { both are oppos } \\
\text { functions - peo }\end{array}$ \\
\hline Feeling & whether it's good or not & weight and value & e - Jung called these \\
\hline Sensation & sometl & sensual perception & both are opposite perceiving functions - \\
\hline Intuit & $\begin{array}{l}\text { where } \\
\text { where }\end{array}$ & $\begin{array}{l}\text { possibilities and } \\
\text { atmosphere }\end{array}$ & $\begin{array}{l}\text { people consciously 'prefer' one or the } \\
\text { other - Jung called these functions } \\
\text { 'irrational' }\end{array}$ \\
\hline
\end{tabular}


Table 3

Jung's 8 Psychological Types

\begin{tabular}{lll}
\hline & Type name & \multicolumn{1}{c}{ Type characteristics } \\
\hline 1 & extroverted thinking & analytical, strategic, plans, implements, organises others \\
2 & introverted thinking & contemplative, discovering, theoretical, seeks self-knowledge \\
3 & extroverted feeling & sociable, sentimental, seeks personal and social success \\
4 & introverted feeling & inaccessible, enigmatic, self-contained, seeks inner intensity \\
5 & extroverted sensation & practical, hands-on, pleasure-seeking, hard-headed \\
6 & introverted sensation & intense, obsessive, detached, connoisseur, expert \\
7 & extroverted intuition & adventurous, innovative, seeks novelty, proposes change \\
8 & introverted intuition & idealistic, visionary, esoteric, mystical, aloof \\
\hline
\end{tabular}

In 1962, in a book named A Guide to the Development and Use of the Myers-Briggs Type Indicator, Briggs and Briggs combined and developed Jung's categorization to make it "more useful" in practical life (Briggs \& Briggs, 1962). In their opinion, there are 4 scales represents two opposing "preferences".

- Extraversion or Introversion: the focus or direction or orientation of our behavior outward (Extraversion) or inward (Introversion)

- Sensing or Intuition: how we gather information observed facts and specifics
(Sensing) or what we imagine things can mean (Intuition)

- Thinking or Feeling: how we decide: objective and tough-minded (Thinking) or friendly and sensitive to others and ourselves (Feeling)

- Judging or Perceiving: our method for handling the outside world and particularly for making decisions - do quite soon evaluate and decide (Judging) or continue gathering data and keep options open (Perceiving)

\section{Table 4}

\section{Briggs and Brigg's 4 Scales of Personality}

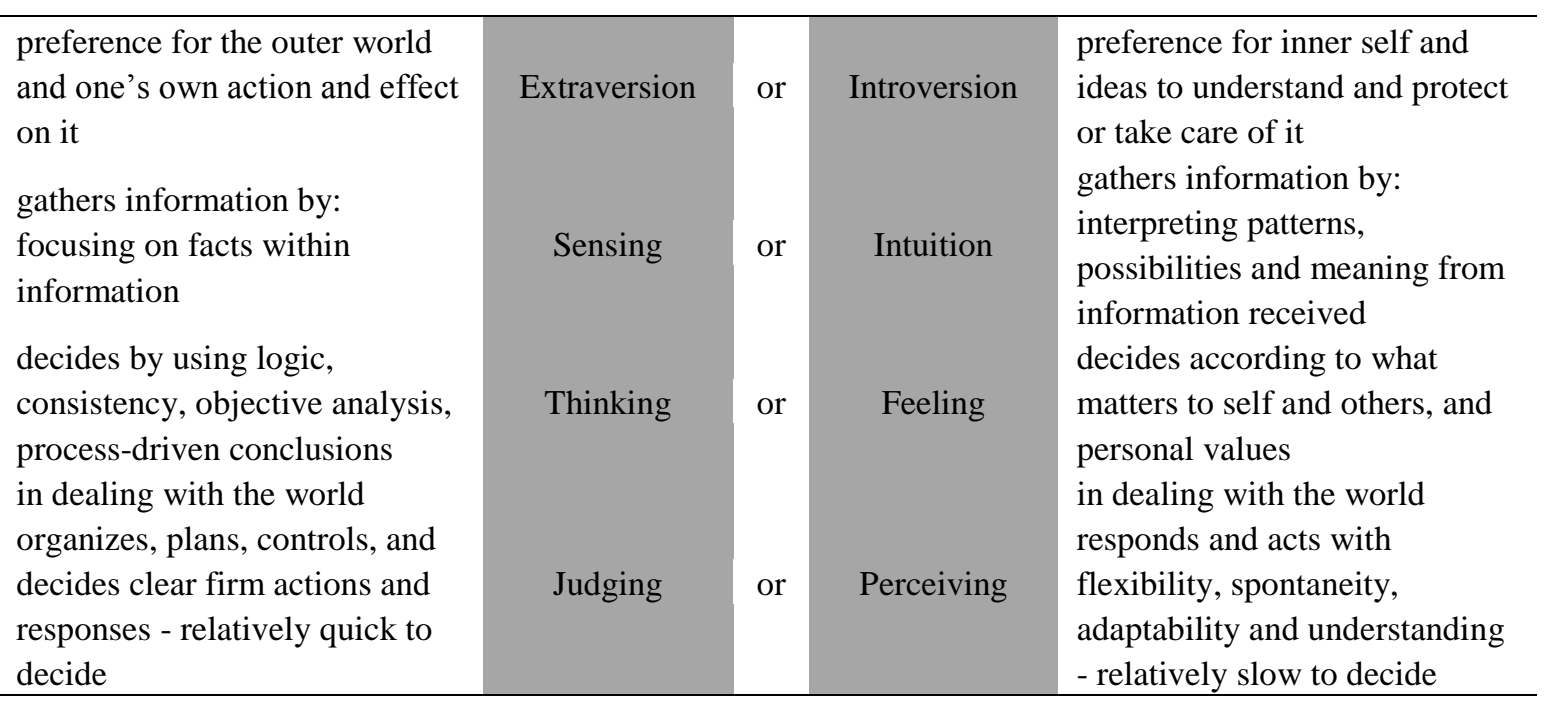

In fact, Briggs and Briggs added the fourth dimension Judging or Perceiving to Jung's three old ones and he succeeded in making categories more understandable. However, the last dimension is somehow related to the third one because they both mention ways of making decisions although they have different approaches.

In Eysenck's 1991 theory, the author just used two scales to measure one's personality:

- Introversion - extraversion

- Stability - instability (unemotionalemotional) 
Table 5

Eysenck's Four Main Types of Personality

\begin{tabular}{|c|c|c|}
\hline & Type name & Type characteristics \\
\hline 1 & $\begin{array}{l}\text { Unstable - introverted } \\
\text { (emotional-introverted) }\end{array}$ & $\begin{array}{l}\text { moody, anxious, rigid, sober, pessimistic, reserved, } \\
\text { unsociable, quiet }\end{array}$ \\
\hline 2 & $\begin{array}{l}\text { Unstable - extroverted } \\
\text { (emotional-extroverted) }\end{array}$ & $\begin{array}{l}\text { touchy, restless, aggressive, excitable, changeable, } \\
\text { impulsive, optimistic, active }\end{array}$ \\
\hline 3 & $\begin{array}{l}\text { Stable - introverted } \\
\text { (unemotional-introverted) }\end{array}$ & $\begin{array}{l}\text { calm, even-tempered, reliable, controlled, peaceful, } \\
\text { thoughtful, careful, passive }\end{array}$ \\
\hline 4 & $\begin{array}{l}\text { Stable - extroverted } \\
\text { (unemotional-extroverted) }\end{array}$ & $\begin{array}{l}\text { sociable, outgoing, talkative, responsive, easy-going, lively, } \\
\text { carefree, leadership }\end{array}$ \\
\hline
\end{tabular}

Apart from understandability, this way of categorizing is helpful for people to find out their own personalities. Therefore, the researcher based on it to conduct the study.

\section{Influences of students' personality on their speaking performance}

In the field of personality types, there have been a number of studies focusing on the relationship between personality types and speaking performance. Most of the studies mentioned two main types of personality which are extrovert and introvert.

The studies (e.g. Dewaele \& Furnham, 2000; Rossier, 1976; Vogel \& Vogel, 1986; Hassan, 2001; Abali, 2006, as cited in Dini, 2018) have found the close relation between extraversion-introversion and participants' oral performance in the target language. Rossier (1976, as cited in Dini, 2018) found that extraversion personality types have positive impacts on oral performance. Dewaele and Furnham (2000, as cited in Dini, 2018) shared the same idea. They thought that extroverted students produce longer speaking performances than introverted ones. Extroverts are also more active than introverts in organizing ideas.

\section{METHODOLOGY}

\section{Research questions}

The research aims to answer these three questions:

1. What are the common personalities of first-year mainstream students of FELTE, ULIS, $V N U$ as perceived by the students?

2. How do the personalities of first-year mainstream students of FELTE, ULIS, VNU affect their performance in speaking activities? Do those personalities help to improve or reduce the effectiveness?

3. What are possible recommendations to reduce negative influences and increase positive ones as perceived by the speaking teachers of first-year mainstream students?

\section{Research design}

The paper is a case-study which focuses on a small group of first-year students from FELTE, ULIS. The reason for choosing this approach is that case-study is suitable for the papers whose focus is to answer "how" questions (Yin, 2003). In fact, one main question for this research is "How do the personalities of first-year mainstream students of FELTE, ULIS, VNU affect their performance in speaking activities?"; therefore, case-study is a suitable approach.

This paper uses the mixed methods which combine elements of qualitative and quantitative approaches. Specifically, the study collects and analyzes both numeric data from the survey and non-numeric data from the interview and observation. This combination helps the researcher have adequate information to find the answers for the research questions.

\section{Participants}

\subsection{First-year students from FELTE, ULIS, VNU}

To seek the answers for the two first research questions, fifty two first-year students from FELTE, ULIS, VNU were involved in the process of data collection. Specifically, the students were picked up randomly because "random sampling" can help to "minimize the effects of any extraneous or subjective variables that might affect the outcomes of the survey 
study" (Hoang \& Nguyen, 2006, as cited in Vu, 2007, pp. 30-31).

\subsection{Speaking teachers}

Experienced speaking teachers at Division 1, FELTE were invited to be involved in the data collection process of the research paper. The reason is that the teachers who have experiences in teaching can understand their students' personality more easily than inexperienced ones. After a long time of teaching, the teacher can give valuable suggestions for students to overcome difficulties in speaking activities caused by their own personalities. In the process of data collection, these two teachers were asked about the influences of personalities on students' performance in speaking lessons. Then they suggested solutions for students as well as teachers to reduce negative influences and increase positive ones. Because of limitation of time, only two speaking teachers were involved in the study.

\section{Data collection instruments}

To find adequate results for the paper, three data collection instruments were used including questionnaires, interviews and class observation. The researcher had to combine these three instruments to have the solid answers for the research questions. Among these three instruments, the information from the questionnaire was the base for the whole study.

\subsection{Questionnaires}

The questionnaire was divided into two main parts. The first part included twenty-two yes/no questions collected and adapted from The short-form revised Eysenck personality questionnaire (EPQ-S): A German edition (Francis, Lewis \& Ziebertz, 2006). The purpose of this part was to find out the personality types of fifty-two students who took part in the survey. The second part consisted of twenty statements which were designed according to Likert scales. This part focused on influences of students' personality types on their performance in speaking lessons.

\subsection{Interviews}

The interviews with four students of four different personality types aimed at finding out the clearer results for the influences of personality types on students' oral performance. There were totally six questions in the interview schedule for students and most of them focused on the second research question. Moreover, relaxing conversations between the interviewer and interviewees were conducted to establish the interaction between the participants of the interviews. Based on that, the researcher could see and judge the interviewees' personality types more clearly to have more exact results.

Likewise, two experienced teachers were asked to take part in the interviews. The main function of these interviews was to find out possible solutions to reduce negative influences of personality types on students' performance in speaking activities and increase the positive effects. Besides, some more questions were raised to ask the teachers about the importance of understanding students' personality and the influences of personality on their speaking performance.

\subsection{Classroom observation}

The speaking performance of the four students who took part in the interview was observed in two lessons. The aim of this part was to find out influences of students personality types on their performance in speaking classes perceived by the researcher. In all those classroom observations, a sample of observation checklist designed by the researcher was used. There was a five-criteria set in the checklist for the researcher to give comments. They were students' involvement and excitement, leadership, noise and mistakes, use of Vietnamese as well as ideas and arguments.

\section{Data analysis procedure}

To find out the answer for the three research questions, the collected data was classified. To be specific, the answer for the first question can be found from the first part of the questionnaires. Then the second part of the questionnaires, the observation's content and students' responses helped to solve the second research question. Lastly, the teachers' answers and suggestions were the key to the third question of the study.

As for the first research question, information on personality types and characteristics of first-year students was 
gathered from the first part of the survey questionnaires which consisted of twenty one yes/no questions. To find out the result, the researcher counted the number of the answers Yes and No of each student. Then, a pie chart was formed to compare the number of different personality types of students. Finally, some outstanding characteristics of each type of students' personality which may influence their performance speaking lessons would be described.

Regarding the second question, the researcher synthesized to find out the personality types in turn. The information for this research question was revealed from the second part of the questionnaires. Because all of the students' answers showed different levels of agreement, they were converted into a fivepoint scale. In details, a maximum of five points referred to students' strong agreement with the statements in the questionnaires. This score gradually decreased from five to one for strong disagreement. At last, the number of students' responses for each statement in different levels (from strongly agree to strongly disagree) was counted. They were all inserted into a table to show the influences of students' personality on their speaking performance. Moreover, the information from the classroom observation and the students' responses in the interviews were added to show clearer results.

With the last question of the study, the researcher took advantage of the teachers' ideas in the interviews to find out the solution for negative influences and help students have the best result in speaking classes.

\section{RESULTS AND DISCUSSION}

\section{Research question 1: The common personalities of first-year students of FELTE, ULIS, VNU as perceived by the students}

The answer for the common personalities of first-year students of FELTE, ULIS, VNU was found out after classifying information in the first research question. The answer to this research question was a surprise because the number of extroverted students was much bigger than the number of introverted ones. In short, the comparison among the four types of personalities of first-year students at FELTE,
ULIS, VNU can be summarized in the table hereafter.

\section{Table 6}

Common Personalities of First-Year Students at FELTE, ULIS, VNU

\begin{tabular}{|l|l|}
\hline Types of personality & Number of students \\
\hline Introverted-Unstable & 6 \\
\hline Introverted-Stable & 2 \\
\hline Extroverted-Unstable & 26 \\
\hline Extroverted-Stable & 18 \\
\hline Total & 52 \\
\hline \multicolumn{2}{|l|}{ Or we can see the comparison among these }
\end{tabular}
four types more clearly in the chart hereafter.

\section{Chart 1}

Common Personalities of First-Year Mainstream Students
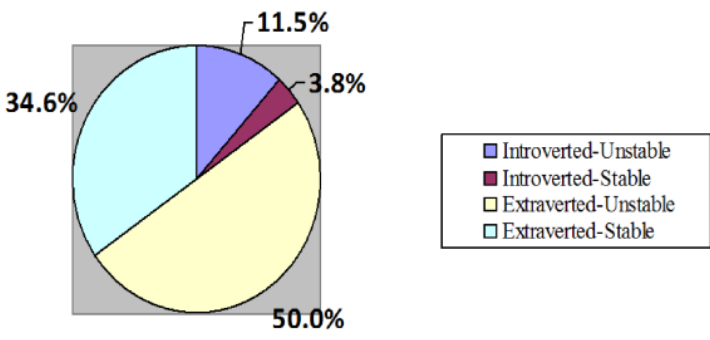

According to the pie chart above, half of the students are Extroverted-Unstable type. Meanwhile, $34.6 \%$ of them are ExtrovertedStable; $11.5 \%$ are Introverted-Unstable students and only $3.8 \%$ are Introverted-Stable ones. Thus, it can be clearly seen that the number of extroverted students who are believed to be sociable, active and out-going is much bigger than introverted ones who are quiet and passive. This result is a bit surprising because the participants of the study are freshmen at university who are often believed to be quiet and shy. This result also brings some expectations about activeness of the students in the classroom's speaking activities.

Also, the students' characteristics of each personality type were revealed from the data collection process. First, it can be concluded that introverted-unstable people are quite excited in their daily life with familiar people but not very active and a little bit shy. To be specific, they are talkative, enjoy meeting people especially their friends. However, they cannot take the initiative in making new 
friends, rapidly get involved in social life at a new workplace or get a party going and are not considered a lively person by others. This result is partially similar to Eysenck's description of introverted-unstable people who are "quiet" and "unsocial" (Eysenck, 1991). Moreover, according to Eysenck, introverted people like being alone and do not want to be with other people.

Besides, most of the introverted-unstable students agree that they are worrying and usually feel lonely as well as suffer from "nerves" and are troubled about feelings of guilt. Their mood often goes up and down. They even feel "just miserable" for no reason and frequently worry too long after an embarrassing experience. In addition, their feelings are easily hurt, they are short-tempered and often feel fed-up. Overall, with all the characteristics analyzed, introverted-unstable students may not be very active and excited in pair work and group work in speaking lessons. Moreover, because they are moody, anxious and rigid, they may not be able to control their temper in discussions and can cause quarrels. With those characteristics, perhaps they are not good leaders when working in pairs or groups.

Secondly, as for introverted-stable students, their extraversion is quite similar to introvertedunstable ones'. Their answers in the questionnaires reveal that they are rather talkative and excited about meeting people but are not very lively and quite passive. Besides, these students say they are not worrying and short-tempered people who do not worry too long after an embarrassing experience and are not often troubled about feelings of guilt. All of them are not nervous; do not often feel lonely, fed-up, and miserable for no reasons and suffer from "nerves". Moreover, their feelings are not easily hurt. This result is on the contrary with introverted-unstable ones but coincides with the opinion about introverted-stable people when they are often described as calm, reliable and controlled. Thus, it can be guessed that introverted-stable students may be not very excited and involved in pair work and group work speaking activities. However, unlike introverted-unstable ones, these students are calm and controlled. Therefore, they may know how to keep temper in discussion so as not to cause unexpected arguments.

Thirdly, regarding extroverted-stable students, they are mostly lively and talkative people who like meeting and mixing with people and friends. They are also quite active when usually taking the initiative in making new friends and rapidly getting involved in social life at a new workplace. Most of them can also let themselves go and enjoy themselves at a lively party and like plenty of bustle and excitement around them. Also, most of the students affirmed they are considered lively people by their friends and more than half of them can get a party going. Surprisingly, only one-third can easily get some life into a rather dull party. Moreover, as for extroverted-stable people, Eysenck described them as easy-going, carefree and have good leadership. In comparison with the result from the questionnaires, it is quite similar because most extroverted-stable students described themselves as not worrying, nervous and shorttempered people. The majority of them do not usually feel lonely, miserable as well as their feelings are not easily hurt but their mood often goes up and down. Thus, with these characteristics, extroverted-stable students may be active and excited in speaking lessons. They may also be enthusiastic to raise ideas and have interesting ones. Moreover, these students may be able to be good leaders in their pairs and groups.

Lastly, concerning extroverted-unstable students, most of them agree that they are talkative and rather lively. These students also enjoy meeting new people and having plenty of bustle and excitement around them. However, nearly half of the students cannot let themselves go and enjoy themselves at a lively party. Besides, almost fifty percent of them are unable to get a party going and easily get some life into a rather dull party. Thus, it can be concluded that although these students are talkative and lively, they are not very active. This result is quite surprising because extroverted people are often thought to be active and excitable (Jung, 1921). Almost all of the extroverted-unstable students taking part in the data collection process conclude that they are worrying and short-tempered people. These students also agree that their mood often goes up and down and their feelings are easily hurt. Moreover, they affirm that they ever feel miserable for no reason and often feel lonely. However, nearly a half of them say they are not nervous people. Overall, extroverted-unstable students are optimistic, active, excitable, touchy and 
changeable. Therefore, in pair work and group work speaking activities, they may be excited and involved in but aggressive to cause quarrels.

\section{Research question 2: Influences of personality on students' performance in speaking lessons of first-year students, FELTE, ULIS, VNU}

The answer for the second research question was revealed from the second part of the questionnaires, the information from the classroom observation and the interviews with four students of four personality types. The influences of each personality type were specifically analyzed according to two criteria: Involvement and excitement and leadership. Regarding the questionnaires, students answered by giving their opinions on the statements from strongly disagree to strongly agree. To be specific, there are totally five scales which were converted into a five-point scale, 1 pt: strong disagree, 2 pts: disagree, 3 pts: neutral, 4 pts: agree, 5 pts: strongly agree.

\subsection{Unstable-Introverted students \& Stable- Introverted students}

\subsubsection{Involvement and excitement}

Regarding unstable-introverted students who are believed to be unsociable and quiet (Eysenck, 1991), they admitted that they were not really involved in activities in speaking classes. Their "quiet" characteristic was clearly shown in their performance in those kinds of activities which was specifically illustrated in the table hereafter.

Table 7

A Summary of Unstable-Introverted and Stable-Introverted Students' Involvement and Excitement in Pair Work and Group Work

\begin{tabular}{llll}
\hline \multicolumn{1}{c}{ Statements } & $\begin{array}{l}\text { Unstable- } \\
\text { Introverted }\end{array}$ & $\begin{array}{l}\text { Stable- } \\
\text { Introverted }\end{array}$ \\
\hline 1 & I am really involved and motivated & 3.17 & 3.0 \\
2 & I take advantage of chances to use English & 3.33 & 3.5 \\
3 & $\begin{array}{l}\text { I feel excited in these activities because I have chance to compete } \\
\text { with my friends }\end{array}$ & 3.0 & 3.0 \\
& $\begin{array}{l}\text { I feel more secure when working with friends instead of talking } \\
\text { to the teacher }\end{array}$ & 3.5 & 3.5 \\
5 & I dominate other friends in my group & 2.33 & 1.5 \\
\hline
\end{tabular}

As it can be clearly seen from the table above, the results for two groups were quite similar to each other. Both groups of students were not very involved and motivated in speaking activities as well as did not really take advantage of chances to use English in those activities because the overall mark of students' agreement was just about three over five points. However, the information collected from the interview was different. An unstable-introverted student said that he was quite involved and excited in speaking activities. Moreover, this student affirmed he tried to take advantage of chances to use English in those activities and "the chance to be the presenter for my group". This totally fitted with the results from the observation of this student's performance. Through the classroom observation, the researcher found out that this unstableintroverted student was quite involved in the activities and sometimes fought to be the speaker of his group. In contrast, a stableintroverted student admitted in the interview that she did not take advantage of chances to use English because she was still afraid to communicate in English. Moreover, she shared that if she had chances to work with her close friends, she would feel free to give opinions and be involved in the activities. Overall, it can be concluded that both unstable-introverted and stable-introverted students did not involve in speaking classes; however, some of unstableintroverted ones still tried to overcome the shortcomings of their personality to participate in and practice speaking English. These students should be complimented when they are aware of their weaknesses.

Beside the involvement, this table showed that most of the students felt more secure when working with their friends' instead of talking to the teacher. The average mark for this one is 3.5 over 5 points which is the highest one among 
five criteria. The interviewed unstableintroverted student agreed with this idea when he stated: "I feel working with the teacher is not very comfortable. Working with my friends is safer". Similarly, one student from the stableintroverted group added that she liked working with friends because it was much safer than talking to the teacher. In addition, the classroom observation also showed that the stableintroverted student did not actively participate in the activities when she spent most of the time listening to other members. Not only may the students of this personality trend but also other kinds of students feel safer to work with friends than to work with teachers. The reason is that friends are close to them; therefore, they are willing to raise ideas or share opinions. When talking to teachers, students are normally afraid of making mistakes.

Last but not least, because these students did not actively participate in speaking activities, they did not dominate their friends in discussions. The average mark for this criterion was only about 2.3 over 5 points for the unstable-introverted group and 1.5 for the stable-introverted group which was the lowest one. In the meantime, the result from the classroom observation and the interview shared the same ideas. When being asked about this problem, the unstable-introverted student answered he could not dominate other friends because they were very energetic, dynamic and quick-minded. Similarly, the stable-introverted student said she was quiet in speaking activities and the researcher witnessed she only talked at the beginning of the activities and then sat to listen to others.

Overall, although both unstable-introverted and stable-introverted students felt safer when working in groups, they did not involve themselves as well as did not dominate their friends in those activities. This result can be easily guessed based on their analyzed characteristics: unstable-introverted group as "quiet" and "unsocial" and stable-introverted group as "careful" and "passive" (Eysenck, 1991). However, if the students are aware of the weakness in their personality, they can have suitable adjustment to have the best results in speaking lessons.

\subsubsection{Leadership}

According to Eysenck's theory about four types of personality in 1991, unstableintroverted and stable-introverted were not the type which had good leadership. Comparing with the information collected from the data collection procedure, Eysenck' idea is quite true when there were few students affirming that they could be the group leaders in pair work and group work activities. The result from the questionnaires was clearly shown in this table:

Table 8

A Summary of Unstable-Introverted and Stable-Introverted Students' Leadership in Pair Work and Group Work

\begin{tabular}{lll}
\hline Statements & $\begin{array}{l}\text { Unstable- } \\
\text { introverted }\end{array}$ & $\begin{array}{l}\text { Stable- } \\
\text { introverted }\end{array}$ \\
\hline 1 & $\begin{array}{l}\text { I help other group members when they have difficulties } \\
2\end{array} \quad \begin{array}{l}\text { I play as the group leader in my group to lead my friends to } \\
\text { finish the task }\end{array}$ & 3.67 \\
$\begin{array}{l}\text { I respect others' ideas and listen to them whenever they raise } \\
\text { voice }\end{array}$ & 3.0 & 2.5 \\
\hline
\end{tabular}

Thanks to the analysis from the table, it can be concluded that most of the students participating in the survey helped their group members when they had difficulties and respected others' ideas. More than a half participating students agreed with these statements and the average mark was 3.67 for unstable-introverted and 3.5 for stableintroverted which was rather high. However, only two among six unstable-introverted students said that they played as the group leaders in their groups to guide other members to finish the task, which led to the low average mark: three over five. Similarly, both of stableintroverted students were not sure about their leadership when the average mark for this claim was only 2.5 over five points. This result quite fitted with the information from the classroom observation when the researcher realized both the unstable-introverted student and the stableintroverted one did not show his leadership in speaking activities. In contrast, in the interview, the unstable-introverted student said he was normally the leader in his group, but only in the 
presentation stage because he usually volunteered to become the presenter. In the researcher's opinion, this does not mean he played as a leader but only a volunteer speaker.

To sum up, both unstable-introverted and stable-introverted students did not show leadership in speaking lessons although they still helped their friends overcome difficulties as well as respected others' ideas. The result of this part is not surprising because unstableintroverted students are not only "quiet", "unsociable" but also "anxious" and "rigid" (Jung, 1921). These characteristics are not suitable for them to play as the leader. Also, stable-introverted students who were described as calm and controlled cannot be a leader because of their passiveness. They are also not confident enough to be a leader. If these students want to have the best performance in speaking activities, they should be aware of their shortcomings and try to reduce the influences of those weaknesses.

\subsection{Unstable-Extroverted \& Stable- Extroverted Students}

\subsubsection{Involvement and excitement}

Both unstable-extroverted people who are excitable and active (Eysenck, 1991) and stable-extroverted ones who are described as sociable, out-going and talkative showed their involvement in pair work and group work in speaking lessons.

\section{Table 9}

A Summary of Unstable-Extroverted and Stable-Extroverted Students' Involvement and Excitement in Pair Work and Group Work

\begin{tabular}{llll}
\hline Statements & $\begin{array}{l}\text { Unstable- } \\
\text { Extroverted }\end{array}$ & $\begin{array}{l}\text { Stable- } \\
\text { Extroverted }\end{array}$ \\
\hline 1 & I am really involved and motivated & 3.23 & 3.78 \\
2 & I take advantage of chances to use English & 3.38 & 3.67 \\
3 & $\begin{array}{l}\text { I feel excited in these activities because I have chance to } \\
\text { compete with my friends }\end{array}$ & 3.23 & 3.88 \\
4 & $\begin{array}{l}\text { I feel more secure when working with friends instead of } \\
\text { talking to the teacher }\end{array}$ & 3.54 & 3.63 \\
5 & I dominate other friends in my group & 2.11 & 3.56 \\
\hline
\end{tabular}

The above table revealed the participation of both unstable-extroverted and stableextroverted students. According to the result, these students were quite involved and excited in speaking activities. However, the result showed that more stable-extroverted students thought they were involved than unstableextroverted ones. Besides, over a half of the students did try to take advantage of chances to use English in those activities. The highest point in the unstable-extroverted column was for the statement of safety when working with friends instead of talking to the teacher. And the highest point in the stable-extroverted column was for statement 4 . These students felt more secure when working with friends instead of talking to teachers. However, in the interview, the stable-extroverted student did not agree because he considered teachers as his friends, but working with friends helped him feel more confident and critical. Also in the interview, the unstable-extroverted student said she was very enthusiastic in the activities and talked so much in discussions. The researcher shared the same idea when observing her performance. She was over-excited and talked most of the time.

Regarding students' domination, surprisingly, this statement got the lowest point for both groups. In contrast, the interviewed unstable-extroverted student told that she always dominated their friends in her groups. The classroom observation also proved the truthfulness of her saying when the researcher found she did not save time for others to talk. On the contrary, the stable-extroverted student said he did not normally dominate others in his group. However, according to the information from the observation, this student sometimes dominated others when he was over-excited in discussions.

Overall, both unstable-extroverted and stable-extroverted students were quite involved in activities and felt secure to work with friends. Also, most of them did not dominate other friends in discussions. Thus, unlike the students of the two first personality types, 
characteristics of the students of these two types have positive influences on their performance in speaking lessons when they were excited in those activities. These students were guessed to dominate their friends because of their aggressiveness but in fact, they did not.

\subsubsection{Leadership}

Concerning leadership, most of unstableextroverted and stable-extroverted students were not group leaders in discussions although they still helped others and respected their friends' ideas.

\section{Table 10}

\section{A Summary of Unstable-Extroverted and Stable-Extroverted Students' Leadership in Pair Work and Group Work}

\begin{tabular}{llll}
\hline Statements & Unstable-Extroverted & Stable-Extroverted \\
\hline 1 & $\begin{array}{l}\text { I help other group members when they have } \\
\text { difficulties }\end{array}$ & 3.58 & 3.17 \\
2 & $\begin{array}{l}\text { I play as the group leader in my group to lead my } \\
\text { friends to finish the task }\end{array}$ & 2.81 & 3.17 \\
3 & $\begin{array}{l}\text { I respect others' ideas and listen to them } \\
\text { whenever they raise voice }\end{array}$ & 4.23 & 4.5 \\
\hline
\end{tabular}

As can be seen from the table, the last statement got the highest point for both groups, which means that most of the students respected others' ideas and listened to them whenever they raised their voices. The second highest point for the unstable-extroverted group belonged to the first statement. It proved these students helped their friends in discussions. However, most of the unstable-extrovert students were not confident to say they were the group leader, which led to the lowest point 2.81 . The result was quite similar for the stableextroverted group. Only a half of them helped other members when they had difficulties and one third played as the leader in pair work and group work speaking activities. Nevertheless, according to the interview, the unstableextroverted student said she often talked so much in her groups and felt that she was the leader. The interviewed stable-extroverted student also shared he was always the leader in his pairs or groups. He also tried to lead other members to finish the task and helped them if necessary. The information from the observation was different for the two groups. Although the unstable-extroverted student wanted to be the leader in her group, her leadership was not good when she sometimes forced others to do as she asked and spoke too much. On the contrary, the stable-extroverted student showed very good leadership and respected others by being patient to listen to their voice.

To sum up, although unstable-extroverted students helped their group members and respected their ideas, they did not show effective leadership. This result fits with the researcher's guess. Although these students are active, and excitable, their touchy and changeable characteristics prevent them from being a good group leader. Therefore, to have the best performance in group work activities, these students should learn how to control their speaking time and respect other group members more. Meanwhile, most stable-extroverted students showed their respect to their friends' ideas but did not play as the leader as well as help others in difficulties. This result is really surprising because according to Eysenck, people of this personality type had very good leadership. Moreover, some characteristics described above showed that they could be good group leaders. Perhaps the reason is that they are freshmen at university. They do not understand their friends enough and do not have experiences. Then they cannot take advantage of their strength in personalities to have the best performance.

\section{Research question 3: Possible recommendations to reduce negative influences and increase positive ones as perceived by the speaking teachers of first- year mainstream students}

After finding the answer to the second research question, the researcher continued working on the last one. The interviews with the two experienced teachers at Division 1, FELTE, VNU revealed the results for this 
question. These teachers raised interesting ideas to suggest how to reduce negative influences and increase positive ones.

First of all, both of the teachers are experienced when they have been teaching speaking for a long time. For each class, they often work in one semester (fifteen weeks). In their opinion, this amount of time was long enough for them to realize the common personality trend of the whole class as well as some outstanding students, for example some very talkative ones or some really quiet ones. However, the teacher couldn't understand each individual's personality. Moreover, both of the teachers could realize the influences of personality on students' performance in speaking lessons. The reason raised by one of them was that in English learning environment, students did not use their mother tongue, so the communication was not natural. They were learning to communicate; therefore, personality affected students' performance a lot. However, the teachers could not figure out specific influences on each type of personality when being asked. They only could give opinions about effects on extroverted and introverted students. To be specific, from their point of view, extroverted students often performed themselves well and led other members in their groups because they were often excited, enthusiastic and seemed to be interested in communicating and performing. In contrast, introverted ones did not take advantage of talking. In fact, they may participate in the activity but not enthusiastically. They took part only because of the requirement of the activity but did not feel relaxed to involve in. These teachers also added it was the teachers' duty to ensure that the participation of students was relatively equal as well as the chance of practicing and talking must be equally given to each student regardless of the differences in their personality.

Realizing those influences on their students' performance, the teachers recommended some solutions to overcome the problem. The teachers agreed they did not base on each student's personality to divide pairs or groups but based on the requirements of the tasks. Moreover, the arrangement of the classrooms did not allow them to pick up so many students. They often divided groups or pairs by traditional ways such as counting and asking the same numbers to sit together or requiring students in one or two tables to be in one group. Then, if there were any problems with students in discussions, the teacher would have some necessary adjustments.

Regarding pair work, the first suggestion from the teachers was to divide the explicit role for each student. To be specific, in this activity, student A had to do this and student B had to do that. Both of them had to do their own task to finish the whole task of the pair. At that time, whether the student's personality was quiet or talkative, they still must talk at least enough to complete the task assigned to them. Secondly, the teachers shared they changed the chance of speaking for students regularly. For example, if in the first activity, student one talked more than the second student; then in the next activity, the teacher would adjust the roles so that student two had more chance of speaking. Thus, the chance of speaking for each student would increase and be equal. Moreover, the teachers had another way of adjusting students' performance in pair work. That was to assign tasks to each individual to make talkative students speak less and vice versa, quiet ones talk more. For instance, when a quiet student was talking, the more talkative one would be told to do another task such as note-taking.

As for group work, the teachers also had some ways to improve the quality of students' performance regardless of their different personality types. The first solution raised by the teachers was to divide different tasks for each member in one group. For example, dominant members could be asked to do some "quiet" tasks such as note-taking or observing to save the chance for other more introverted and shy students to perform. Secondly, the teacher needed to use different observing methods when dividing roles. For instance, in some cases in one group, the teacher could assign some roles in which students must talk to quiet learners to force them to talk. Or sometimes, based on their observation, the teacher could come to quiet students to elicit and help them involve in the activities. Another way the teachers suggested was to control group work when students came to the board to present. The teachers shared they never called only one student to come to present because volunteer students or group leaders were normally good at speaking. Therefore, the chance of speaking should be saved for other members by randomly calling one member or 
even asking the whole group to present. At that time, the teacher would give marks for each student as well as observe the cooperation among members. Consequently, each member had to be aware of their own task and the minimum requirement for each of them. Another way which could be applied into both pair work and group work was to encourage students by giving bonus points to enthusiastic and active ones. Besides, the teachers also could affirm dynamic students would be given some gifts and quiet ones would receive some punishments.

To sum up, this part has found out the answers for each of research questions thanks to the analysis and discussion of the collected data. Regarding the common personality types of first-year mainstream students, extroverted ones make up the majority. Concerning the influences, although there are some surprising results which are on the contrary to the researcher's guess, each personality type has both positive and negative effects on students' performance. As for possible solutions, some advice about dividing pairs and groups as well as assigning tasks and roles for students was raised by the speaking teachers to solve the problem.

\section{CONCLUSION}

\section{Major findings of the study}

On the whole, the research paper studies the influences of personality on students' speaking performance. Thanks to the analysis and discussion of data collected from questionnaires, interviews and classroom observation, the answers to three research questions were revealed.

As for the first research question, the study confirmed that half of first-year mainstream students of FELTE, ULIS were unstableextroverted, $34.6 \%$ of them were ExtrovertedStable, $11.5 \%$ were Introverted-Unstable students and only $3.8 \%$ were Introverted-Stable ones. Regarding characteristics of each personality type, unstable-introverted students are quite excited in their daily life with familiar people but not very active and a little bit shy. Moreover, they are also moody, anxious and pessimistic like the description of Eysenck in
1950. Belonging to the second personality type, stable-introverted students are similar to unstable-introverted ones in terms of their extraversion trend. However, unlike the students of the first type, they are calm, eventempered and controlled. In the third type, stable-extroverted students show that they are sociable, outgoing and talkative. These students are also carefree and easy-going when they do not worry too much and are not nervous. Lastly, unstable-extroverted students described themselves as talkative and rather lively but not very active because they cannot let themselves go and enjoy themselves at a lively party. Moreover, their mood is changeable and they are moody but not nervous people.

Regarding the second research question, some influences of different personality types on students' performance in speaking lessons have been found out. Firstly, although unstableintroverted students felt safer when working in groups, they did not involve themselves as well as did not dominate their friends in those activities. Moreover, even though these students helped their friends overcome difficulties and respected others' ideas, they did not show leadership in speaking lessons.

Similar to unstable-introverted students, stable-introverted ones felt safer to work with friends instead of talking to the teacher but did not actively join in pair work and group work speaking activities; therefore, they did not dominate their friends when discussing. These students also did not play as a leader in discussions.

Unlike stable and unstable-introverted students, unstable-extroverted ones were quite involved in speaking activities and felt secure to work with friends. However, most of them did not dominate other friends in discussions. Also, although unstable-extroverted students helped their group members in group work and respected their ideas, they did not show effective leadership.

Belonging to the last personality type, stable-extroverted students were involved and excited in speaking lessons and tried to take advantage of chances to communicate in English. Besides, they did not usually dominate their friends in discussions and did not think it was safer to work with friends rather than the teachers. Moreover, although most of the 
stable-extroverted students showed their respect to their friends' ideas, they did not play as the leader as well as help others in difficulties.

After the answers for the first and second research question were found out, some suggestions to reduce negative influences of personality types on students' performance in speaking lessons were proposed. First of all, regarding pair work, the speaking teachers recommended dividing explicit roles for each student. Secondly, the students' chance of speaking should be changed regularly. Moreover, the teachers had another way of adjusting students' performance in pair work. That was to assign tasks to each individual to make talkative students speak less and vice versa, quiet ones talk more.

As for group work, the first solution raised by the teachers was to divide different tasks for each member in one group. Next, the teachers needed to use other observing methods when dividing roles to help quiet students when necessary. Another way the teachers suggested was to control group work when students came to the board to present by randomly calling one member or the whole group to make the presentation. Another way which could be applied into both pair work and group work was to encourage students by giving bonus points to enthusiastic and active ones.

\section{Limitations of the study}

Despite the researcher's effort, the study still has some short-comings because of time limitation and other unexpected factors.

First of all, the number of first-year students participating in the data collection procedure was quite small in comparison with the whole number of students in Division 1. Therefore, the representativeness of them was rather low. Maybe because of this reason, the result for the first research question was quite surprising when the amount of extroverted students was much more than introverted ones.

Secondly, also because of time limitation, there were only two speaking teachers in Division 1 taking part in the interviews. Although the advice and suggestions they gave were really useful, they did not focus on each type of personality but only extraversion and introversion. The reason is that it is not easy for the teachers to understand each student's personality type in just fifteen-week teaching time. They could only realize the common trend of the whole class or some outstanding students.

\section{Suggestions for further studies}

Overall, different personality types have some certain influences on students' performance in speaking activities. Therefore, to have better teaching and learning results, it is necessary for the teachers to understand their students' personality traits. In fact, personality is a very big field in research. This paper only covered a small part of this field. Further studies can be conducted to find out personality influences on foreign language learning.

\section{REFERENCES}

\section{Vietnamese}

Tran, T. H. (2010). Diễn đàn "Sinh viên yếu ngoại ngữ: vì sao?": Cần cải tiến phương pháp giảng dạy. Giáo dục Online. Retrieved November 23, 2018, from http://www.giaoduc.edu.vn/news/chuyen-hoc-duong753/dien-dan-sinh-vien-yeu-ngoai-ngu-vi-sao-can-caitien-phuong-phap-giang-day-148167.aspx

\section{English}

Briggs, I. M., \& Briggs, K. (1962). A guide to the development and use of the myers-briggs type indicator. Businessballs. Retrieved November 29, 2018, from http://www.businessballs.com/personalitystylesmodels.ht m\#carl\%20jung\% $27 \mathrm{~s} \% 20$ personality\%20types

Bui, T. A. D. (2003). Promoting speaking skills for $11^{\text {th }}$ form pupils of English at gifted secondary school through drama activities [Unpublished graduation thesis]. Vietnam National University, Hanoi.

Carver, C. S., \& Scheier, M. F. (2000). Perspectives on personality (4th ed.). Allyn and Bacon.

Chu, H. N. (2003). Using visual aids as an effective way in teaching speaking skills to the $12^{\text {th }}$ form students at upper-secondary schools in Hanoi [Unpublished Graduation Paper]. Vietnam National University, Hanoi.

Dini, T. (2018). The Correlation between Students' Personality and English Speaking Fluency [Unpublished undergraduate thesis]. Ar-Raniry State Islamic University. https://core.ac.uk/download/pdf/293467006.pdf

Eysenck, H. J. (1991). Dimensions of personality: 16, 5 or 3? Criteria for a taxonomic paradigm. Personality and Individual Differences, 12(8), 773790. https://doi.org/10.1016/0191-8869(91)90144-Z

Francis, J. L., Lewis, A. C., \& Ziebertz, G. H. (2006). The short-form revised Eysenck personality questionnaire (EPQ-S): A Hindi edition. Retrieved February 10, 2020, from http://medind.nic.in/icg/t09/i1/icgt09i1p27.pdf

Harmer, J. (1991). The Practice of English Language Teaching ( ${ }^{\text {rd }}$ ed.). Longman. 
Jung, C. G. (1921). Psychological Types. Businessballs. Retrieved November 29, 2018, from http://www.businessballs.com/personalitystylesmodels .htm\#carl\%20jung\%27s\%20personality\%20types

Long, M. H., \& Porter, P. A. (1985). Group Work, Interlanguage Talk and Second Language Acquisition. Retrieved October 21, 2018, from www.course1.winona.edu/.../groupwork_interlanguag etalkandL2acquisition.pdf

Minghe, G., \& Yuan, W. (2013). Affective Factors in Oral English Teaching and Learning. Higher Education of Social Science, 5(3), 57-61. https://docplayer.net/42963932Affective-factors-in-oral-english-teaching-and-learning.html

Moody, R. (1998). Personality Preferences and Foreign Language Learning. The Modern Language Journal, 72(4), 389-401. https://doi.org/10.2307/327751

Nguyen, N. L. L (2018). Developing learner autonomybased foreign language proficiency enhancement model for vietnam's public officials, civil servants and public employees. VNU Journal of Foreign Studies, 34(4), 144-155.

Nguyen, H. T., \& Tran, N. M. (2015). Factors affecting students' speaking performance at Le Thanh Hien high school. Asian Journal of Educational Research, 3(2), 8-23. http://www.multidisciplinaryjournals.com/wpcontent/uploads/2015/03/FACTORS-AFFECTINGSTUDENTS\%E2\%80\%99-SPEAKING.pdf

Nguyen, T. T. M. (2004). Using pairwork and group work to teach conditional sentences at secondary school in Hanoi [Unpublished Graduation Paper]. Vietnam National University, Hanoi.

Nguyen, T. T. M, Pham, M. T., \& Luong, Q. T. (2009). Research methodology. Vietnam National University, Hanoi.

Phares, E. J. (1991). Introduction to psychology (3rd ed.). Harper Collins Publishers.

Truong, T. P (2011). Influences of Personality on Performance of First-year Mainstream Students in Pair Work and Group Work in Speaking Activities [Unpublished undergraduate thesis]. Vietnam National University, Hanoi.

Yin, R. K. (2003). Case study research: Design and methods (3rd ed.). Sage.

Zhang, Y. (2006). The Role of Personality in Second Language Acquisition. Asian Social Science, 4(5), 5859. https://doi.org/10.5539/ass.v4n5p58

\section{APPENDIX 1: QUESTIONNAIRES, INTERVIEW SCHEDULES AND CLASSROOM OBSERVATION CHECKLIST}

\section{PART I}

Please answer the following questions by putting an "X" in the box YES or NO.

\begin{tabular}{ll}
\hline QUESTIONS & YES NO \\
\hline 1 & Are you a talkative person? \\
2 & Are you rather lively? \\
3 & Do you enjoy meeting new people? \\
4 & Can you usually let yourself go and enjoy yourself at a lively party? \\
5 & Do you usually take the initiative in making new friends? \\
6 & Do you rapidly get involved in social life at a new workplace? \\
7 & Do you like mixing with people? \\
8 & Do you like plenty of bustle and excitement around you? \\
9 & Do other people think of you as being very lively? \\
10 & Can you get a party going? \\
11 & Can you easily get some life into a rather dull party? \\
12 & Does your mood often go up and down? \\
13 & Do you ever feel 'just miserable' for no reason? \\
14 & Are your feelings easily hurt? \\
15 & Do you often feel 'fed-up'? \\
16 & Would you call yourself a nervous person? \\
17 & Are you a worrier? \\
18 & Do you worry too long after an embarrassing experience? \\
19 & Are you a short-tempered person? \\
20 & Do you often feel lonely? \\
21 & Are you often troubled about feelings of guilt? \\
22 & Do you suffer from 'nerves'?
\end{tabular}




\title{
PART II
}

Please answer the following questions by putting an " $\mathrm{X}$ " in the box of the appropriate number:

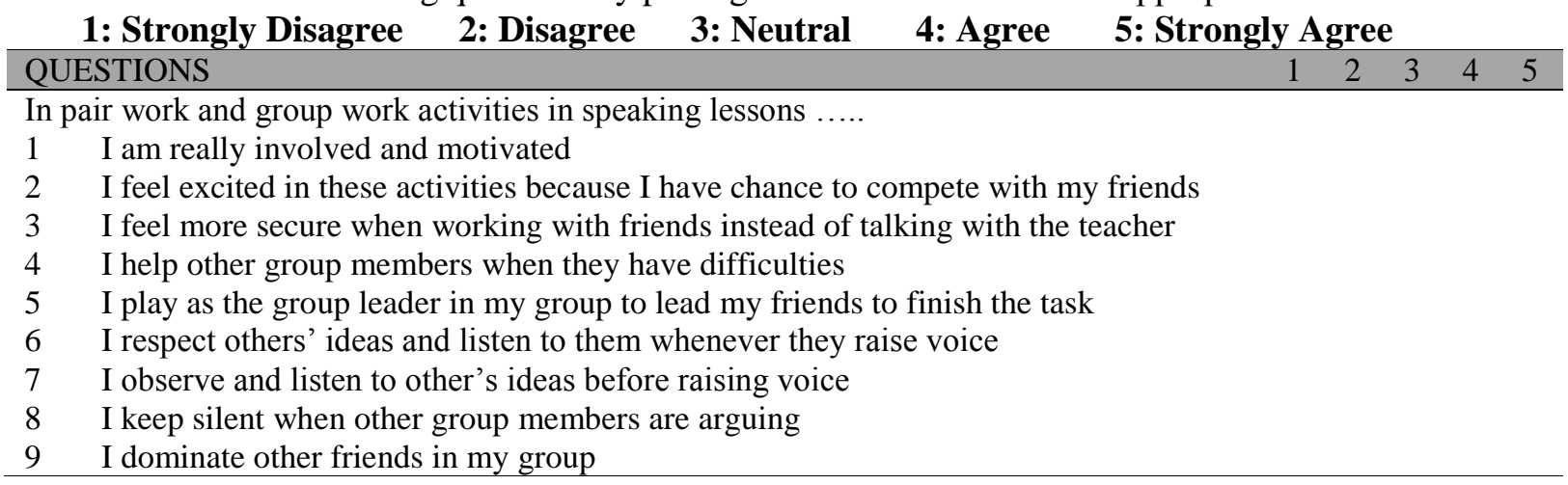

Thank you very much for your help!

\section{ẢNH HƯỞNG CỦA TÍNH CÁCH ĐẾN SỰ THỂ HIỆN CỦA SINH VIÊN TRONG HOẠT ĐỘNG NÓI}

\author{
Trương Thị Phượng \\ Khoa Đào tạo và Bồi duõng Ngoại ngũu, Trưòng Đại học Ngoại ngũ, ĐHQGHN, \\ Phạm Văn Đồng, Cầu Giấy, Hà Nội, Việt Nam
}

Tóm tắt: Nghiên cứu điều tra những ảnh hưởng của tính cách đến sự thể hiện của sinh viên năm thứ nhất trong hoạt động nói, khoa Sư phạm tiếng Anh, trường Đại học Ngoại ngữ, Đại học Quốc gia Hà Nội. Nghiên cứu tập trung vào cả những ảnh hưởng của tính cách lên sinh viên trong các hoạt động của giờ học môn nói và những gợi ý của các giáo viên có kinh nghiệm để giải quyết vấn đề trên. Để đạt được hai mục đích đó, tác giả đã mời 52 sinh viên năm thứ nhất và 2 giảng viên khoa Sư phạm tiếng Anh tham gia nghiên cứu. Các công cụ nghiên cứu bao gồm: bản điều tra khảo sát, phỏng vấn và quan sát lớp học. Những dữ liệu thu thập được cho thấy rằng xu hướng tính cách chung của sinh viên là hướng ngoại - không ổn định. Ngoài ra, một số ảnh hưởng tích cực và tiêu cực của tính cách lên sự thể hiện của sinh viên cũng được phát hiện ra. Dựa vào những kết quả đó, một số gợi ý về cách chia nhóm, chia cặp và phân chia vai trong hoạt động môn nói được hai giáo viên gợi ý để hạn chế những ảnh hưởng tiêu cực và thúc đẩy những ảnh hưởng tích cực.

Tù khóa: hoạt động theo cặp, hoạt động nhóm, tính cách, môn nói 